\title{
Characterization of Neoparamoeba pemaquidensis strains: PCR-RFLP of the internal transcribed spacer region from the amoeba and endosymbiont
}

\author{
Charles G. B. Caraguel ${ }^{1,2}$, Nathanaëlle Donay ${ }^{1,2}$, Salvatore Frasca Jr. ${ }^{3}$, \\ Charles J. O'Kelly ${ }^{4}$, Richard J. Cawthorn ${ }^{1,2}$ Spencer J. Greenwood $^{1,2, *}$
}

\begin{abstract}
${ }^{1}$ AVC Lobster Science Centre and ${ }^{2}$ Department of Pathology \& Microbiology, Atlantic Veterinary College, University of Prince Edward Island, 550 University Avenue, Charlottetown, Prince Edward Island C1A 4P3, Canada

${ }^{3}$ Department of Pathobiology \& Veterinary Science, University of Connecticut, 61 North Eagleville Road, Storrs, Connecticut 06269-3089, USA
\end{abstract}

${ }^{4}$ Bigelow Laboratory for Ocean Sciences, PO Box 475, 180 McKown Point Road, West Boothbay Harbor, Maine 04575, USA

\begin{abstract}
Neoparamoeba pemaquidensis continues to be an ongoing problem for commercial finfish aquaculture and has also sporadically been associated with mass mortalities of commercially relevant marine invertebrates. Despite the ubiquity and importance of this amphizoic amoeba, our understanding of the biology as it applies to host range, pathogenicity, tissue tropism, and geographic distribution is severely lacking. This may stem from the inability of current diagnostic tests based on morphology, immunology, and molecular biology to differentiate strains at the subspecies level. In the present study, we developed a polymerase chain reaction-restriction fragment length polymorphism (PCR-RFLP) method based on the internal transcribed spacer (ITS) region that can accurately differentiate amoeba strains of $N$. pemaquidensis. The investigation focused on the complications of the amoeba ITS microheterogeneity in the development of a subspecies marker and the use of the endosymbiont, Ichthyobodo necator related organism (IRO), ITS region as an alternative marker. The combination of host amoeba and endosymbiont ITS PCR-RFLP analyses was successfully used to correctly identify and characterize an $N$. pemaquidensis isolate from an outbreak of amoebic gill disease in Atlantic salmon Salmo salar from the west coast of North America (Washington State, USA).
\end{abstract}

KEY WORDS: Internal transcribed spacer $\cdot$ Strain marker $\cdot$ PCR-RFLP $\cdot$ Microheterogeneity $\cdot$ Ichthyobodo necator related organism · Parasome

Resale or republication not permitted without written consent of the publisher

\section{INTRODUCTION}

Neoparamoeba pemaquidensis Page, 1987 is a ubiquitous marine amoeba present in free-living and parasitic forms. As a pathogen, N. pemaquidensis is recognized worldwide as the causative agent of amoebic gill disease (AGD) in sea-farmed salmonids (Munday et al. 2001) and non-salmonid fish hosts (Dyková et al. 1995, 1998, 1999, 2000, Fiala \& Dyková 2003). Disease outbreaks in marine invertebrates have also been attributed to $N$. pemaquidensis in both American lobster Homarus americanus (Mullen et al. 2004, 2005) and green sea urchins Strongylocentrotus droebachiensis (as Paramoeba invadens Jones, 1985; Mullen et al. 2005).

The genus Neoparamoeba is identified, in part, by the presence of one or more membrane-bound inclusions ('paranuclear organelle' or 'parasome') near the nucleus of the amoeba. Recent molecular evidence places members of the genus Neoparamoeba in a tight sublineage within the Gymnamoebia (Fiala \& Dyková 2003, Peglar et al. 2003). Molecular phylogenetic analysis has also revealed that the parasome is an endosymbiont closely related to the prokinetoplastid Ichthyobodo necator (Dyková et al. 2003, Moreira et al. 2004). This molecular association forced reconsideration of the 
proper name of this endosymbiont, and the more appropriate name of Ichthyobodo necator related organism (IRO) has been proposed (Caraguel et al. in press).

Several diagnostic methods have been developed for the identification of Neoparamoeba pemaquidensis. Isolation in culture of amoebae and histopathological identification represent primary techniques based on morphological features of the amoeba; however, both methods are inconsistent and lack specificity (Munday et al. 1993, Dyková \& Novoa 2001, Dyková et al. 2005). More specific and sensitive immunological methods incorporating polyclonal antibodies have been designed for screening biological material, including an indirect fluorescent antibody test (IFAT; Howard \& Carson 1993) and an immuno-dot blot test (DouglasHelders et al. 2001). All current immunological techniques, however, have limitations in the specific identification of $N$. pemaquidensis, with reported cross-reactivity of the polyclonal antisera with $N$. aestuarina and Pseudoparamoeba pagei (DouglasHelders et al. 2001).

Because of the difficulties in characterizing Neoparamoeba species, there has been increased use of molecular tools for identification and phylogenetic studies. The $18 \mathrm{~S}$ ribosomal RNA (rRNA) gene was appropriately the first genetic marker used for molecular characterization of the genus Neoparamoeba (Elliot et al. 2001, Fiala \& Dyková 2003, Peglar et al. 2003, Wong et al. 2004, Dyková et al. 2005, Mullen et al. 2005). As a useful specific marker for Neoparamoeba species (Dyková et al. 2005), the 18S rRNA sequences have high levels of similarity (98.1 to 99\%) among sequences from different isolates of $N$. pemaquidensis (Wong et al. 2004). Two nested PCR methods for the detection of $N$. pemaquidensis based on the 18S rRNA gene have been developed to detect and identify the pathogen. The first is specific for $N$. pemaquidensis and is relatively efficient when used after cultureenrichment of environmental and host-derived samples (Elliot et al. 2001, Wong et al. 2004). The second nested PCR generates a 165 base pair product from Paramoebidae/Vexilliferidae amoebae but does not amplify templates from Pseudoparamoeba pagei or Korotnevella hemistylolepis and more importantly does not amplify templates from $N$. pemaquidensis strain ATCC 50172 (Mullen et al. 2005). These PCR protocols clearly illustrate useful features as well as some of the current limitations of molecular characterizations. As with all initial studies, the benefits and applicability will be assessed as more sequence data become available; until then, they should only be used with caution in large-scale diagnostic applications. Moreover, both methods are unable to discriminate isolates at the subspecies level due to the low degree of intraspecific variability of the $18 \mathrm{~S}$ rRNA marker.
The ability to further characterize pathogens at a subspecies or strain level using genetic markers with sufficient variability has revealed previously unrecognized differences in parasite biology and has provided a clearer picture of host-pathogen interactions. In both Giardia duodenalis and Cryptosporidium parvum, genotyping and subtyping of isolates from different hosts have led to the discovery of new species, as well as the distinction of both host-adapted and cosmopolitan species (Caccio et al. 2005). Thus, the characterization of Neoparamoeba pemaquidensis at the subspecies level may provide new information and also allow us to reconsider our current understanding of the geographic distribution, host range, and tissue tropism of this amphizoic amoeba. Firstly, N. pemaquidensis has been isolated from a variety of marine coastal environments from around the world (Fiala \& Dyková 2003) as well as from a diverse assemblage of marine organisms (Cann \& Page 1982). However, it is unknown whether $N$. pemaquidensis detected in tissue or recovered from finfish have the potential to infect invertebrates in geographically nearby locales. Secondly, $N$. pemaquidensis have been characterized as 'pathogenic' when isolated from infected fish (e.g. ATCC 50172) and as 'environmental' when found in the marine ecosystem (e.g. CCAP 1560/5). Although pathogenic strains can lose virulence during in vitro culture (Morrison et al. 2005), it is currently unknown whether environmental strains can become pathogenic. Thirdly, N. pemaquidensis is an external parasite during finfish gill infections (Adams et al. 2004) but an internal parasite in lobsters and sea urchins (Mullen et al. 2004, 2005). Therefore, it has yet to be determined if particular strains of $N$. pemaquidensis have specific host or tissue tropisms. Clearly, subspecies identification of $N$. pemaquidensis by using a broadly applicable molecular marker could have direct applications in disease monitoring, surveillance, and epidemiological studies during outbreaks.

The internal transcribed spacer (ITS) region, located between the 18S and 28S rRNA genes, was targeted to explore the level of intra-specific and intra-genomic variability (Brown et al. 2004, Ruggiero \& Procaccini 2004, Beszteri et al. 2005). The Neoparamoeba pemaquidensis ITS region showed both qualitative and quantitative inter-strain variability that was mainly localized to the more variable regions of the ITS 1 and ITS 2 (Caraguel et al. in press). A detailed investigation of intra-strain variability revealed the existence of very high levels of microheterogeneity in these ITS regions. The existence of this intragenomic variability potentially precluded the use of the $N$. pemaquidensis ITS region as a good genetic marker. Phylogenetic analysis of the $N$. pemaquidensis ITS region revealed that microheterogeneity did not 
obscure the monophyletic nature of the sequences derived from individual isolates, which led to the further consideration of this region as a subspecies marker. Analysis of the endosymbiont (IRO) ITS region revealed both qualitative and quantitative inter-strain variability among the IRO isolates and showed low to non-existent levels of microheterogeneity that likewise did not obscure the phylogenetic monophyly of the IRO-ITS sequence data from individual isolates (Caraguel et al. in press). Since the IRO is intimately associated and coevolves with the amoeba host, the endosymbiont ITS region may provide an alternative target for $N$. pemaquidensis diagnostic test development (Caraguel et al. in press).

The purpose of the present study was to develop a molecular method based on restriction fragment length polymorphism (RFLP) of the Neoparamoeba pemaquidensis ITS region that would accurately identify amoeba strains. The investigation focused on the complications of the amoeba ITS microheterogeneity in the development of a subspecies marker and the use of the IRO ITS region as a complementary or alternative marker. The amoeba and IRO PCR-RFLP analyses were used to assess an outbreak of AGD in Atlantic salmon Salmo salar from the west coast of North America (Washington, USA).

\section{MATERIALS AND METHODS}

Amoeba isolates. Initially, all 6 isolates of Neoparamoeba pemaquidensis that were available from public culture collections at the American Type Culture Collection (ATCC), and the Culture Collection of Algae and Protozoa (CCAP) were acquired and analyzed. From these 6 isolates, 4 strains were defined within $N$. pemaquidensis by Caraguel et al. (in press) based on ITS sequence similarity (Table 1). The CCAP 1560/4 isolate, representing the strain CCAP, was grown in MY75S agar medium at room temperature $\left(19\right.$ to $\left.22^{\circ} \mathrm{C}\right)$. The isolate ATCC 30735 , representing the strain ATCC 30735, and the isolate ATCC 50172, representing the strain ATCC 50172, were cultured in ATCC medium 994 agar medium at room temperature $\left(19\right.$ to $22^{\circ} \mathrm{C}$ ) bacterized with Klebsiella pneumoniae. Urchin amoeba UA6, representing the strain UA, was cultivated at $15^{\circ} \mathrm{C}$ in L1 agar medium and fed with Enterobacter aerogenes. N. aestuarina Page, 1987 was cultured in liquid ATCC medium 994 at room temperature $\left(19\right.$ to $\left.22^{\circ} \mathrm{C}\right)$.

Amoebae were isolated from an AGD outbreak in Atlantic salmon that occurred in late fall 2004 (Washington, USA). Several protists were extracted from gills by the method of Zilberg et al. (2001). Two morphologically distinct amoebae were isolated, and

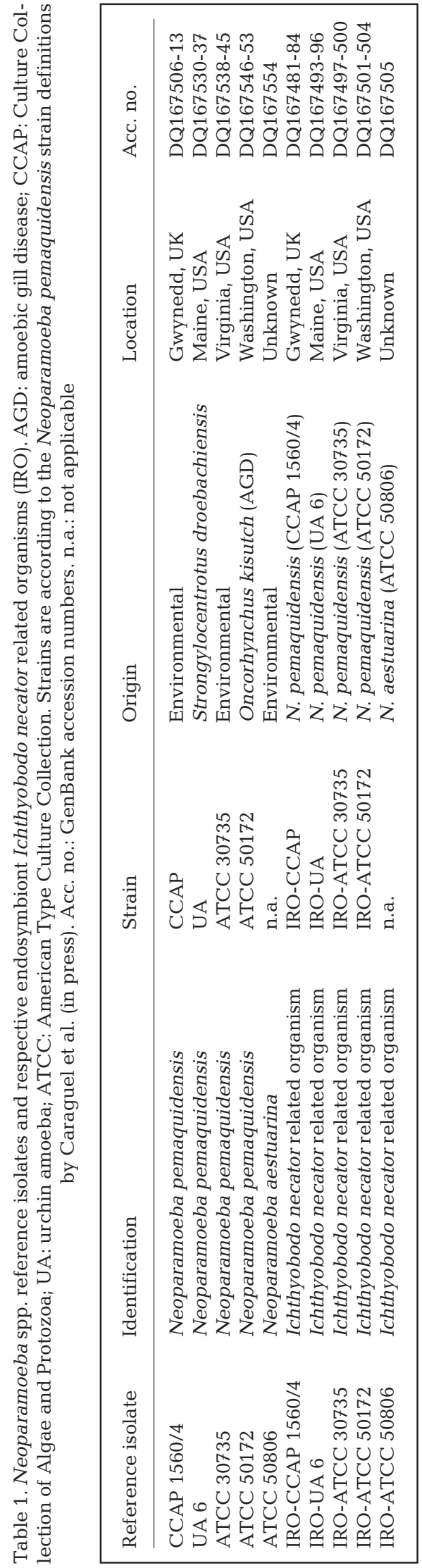


clonal cultures were established in solid ATCC medium 994 bacterized with Klebsiella pneumoniae. The first isolate, AVCLSC-001, was flattened and irregularly fan-shaped, and an IRO could be easily observed with light microscopy. The second amoeba, AVCLSC-002, was also flattened and irregularshaped; however, unlike AVCLSC-001, AVCLSC-002 displayed numerous long and dark uroidal filaments and a denser intracellular compartment, and no IRO was observed.

Genomic DNA extraction. Amoebae were detached from the agar using $2 \mathrm{ml}$ of sterile seawater spread directly on plates; cell suspensions were collected by centrifugation for $5 \mathrm{~min}$ at $6500 \times g$ at room temperature. DNA was extracted using the GenElute ${ }^{\mathrm{TM}}$ Mammalian Genomic DNA Miniprep Kit (Sigma-Aldrich). DNA concentration was determined spectrophotometrically; quality was assessed by electrophoretic separation in a $0.8 \%$ agarose gel containing $0.5 \mu \mathrm{g} \mathrm{ml}^{-1}$ ethidium bromide.

Amplification of ITS regions. The ITS region of Neoparamoeba pemaquidensis was amplified using the specific forward Neoparamoeba spp. primer fNpHx49 (5'-GGGTAGAGCGAGTTTGTTGTG-3'), positioned on the $3^{\prime}$ end of the 18S rDNA gene (reverse complement of the primer $\mathrm{rNp}-\mathrm{Hx} 49$ of Wong et al. 2004) and the universal reverse primer NLR 204/21 (5'-ATATGCTTAARTTCAGCGGGT-3'), positioned on the $5^{\prime}$ end of the 28S rDNA gene (Van der Auwera et al. 1994). Approximately 10 to $50 \mathrm{ng}$ of genomic DNA were amplified in a $25 \mu \mathrm{l}$ reaction containing 2.5 pmol of each primer fNp-Hx49 rDNA and NLR 204/21 in the presence of the following reagents contained in a pure TAq Ready-To-Go PCR Bead (Amersham Biosciences): $200 \mu \mathrm{M}$ of each dNTP, $1.5 \mathrm{mM}$ $\mathrm{MgCl}_{2}, 10 \mathrm{mM}$ Tris-HCl (pH 9), $50 \mathrm{mM} \mathrm{KCl}$, and $2.5 \mathrm{U}$ of Taq DNA polymerase. The amplification protocol was carried out in an MJ Research PTC-200 thermal cycler (Bio-Rad Laboratories) under the following conditions: an initial denaturation at $94^{\circ} \mathrm{C}$ for $2.5 \mathrm{~min}$, followed by 30 cycles consisting of denaturation at $94^{\circ} \mathrm{C}$ for $1 \mathrm{~min}$, annealing at $50^{\circ} \mathrm{C}$ for $30 \mathrm{~s}$, and extension at $72^{\circ} \mathrm{C}$ for $1 \mathrm{~min}$. Final extension was at $72^{\circ} \mathrm{C}$ for $10 \mathrm{~min}$.

The ITS region of IROs was amplified using the specific ITS forward primer IRO-F-ITS (5'-GCGCACTA CAATGACAAAGTG-3') positioned on the 3' end of the 18S rDNA gene, and the universal eukaryote reverse primer ITS4 (5'-TCCTCCGCTTATTGATATGC-3'), positioned on the $5^{\prime}$ end of the 28S rDNA gene (Ristaino et al. 1998). Each $25 \mu \mathrm{l}$ reaction included $50 \mathrm{ng}$ of genomic DNA with the same concentration of reagents as described above. Thermocycling conditions were the same as above. Amplicon size and quality were assessed for both reactions by electrophoretic separation in a $1.0 \%$ agarose gel containing $0.5 \mu \mathrm{g} \mathrm{ml}^{-1}$ ethidium bromide.

Sequence analyses and restriction mapping. Restriction mapping was initially pursued by analyzing Neoparamoeba and IRO ITS region sequences available in GenBank (accession numbers in Table 1; Caraguel et al. in press). For each isolate, a consensus sequence was constructed and analyzed by restriction mapping using BioEdit software (Hall 1999). The restriction endonuclease AseI was selected to discriminate Neoparamoeba ITS region PCR products, and 2 restriction endonucleases, AleI and NgoMIV, were chosen to separate IRO ITS region amplicons. The cleavage patterns of ITS sequences were predicted by in silico simulation using 'NEBcutter V2.0' software (http://tools.neb.com/NEBcutter2/index.php).

RFLP. Five $\mu$ l of the $25 \mu \mathrm{l}$ Neoparamoeba reaction mixture were digested with $5 \mathrm{U}$ of the restriction enzyme AseI (New England Biolabs) as directed by the manufacturer in a final volume of $20 \mu \mathrm{l}$ at $37^{\circ} \mathrm{C}$ for either 1 or $3 \mathrm{~h}$. Similarly, $8 \mu \mathrm{l}$ of the $25 \mu \mathrm{l}$ IRO reaction mixture were digested with $5 \mathrm{U}$ of $\mathrm{NgoMIV}$ and $2 \mathrm{U}$ of AleI (New England Biolabs) as directed by the manufacturer in a final volume of $20 \mu \mathrm{l}$ at $37^{\circ} \mathrm{C}$ for either 1 or $3 \mathrm{~h}$. Following incubation, the digestion products were separated by electrophoresis on a $2.0 \%$ agarose gel containing $0.5 \mu \mathrm{g} \mathrm{ml}^{-1}$ ethidium bromide.

Species confirmation. The identities of the unknown amoebal isolates were confirmed by partial sequencing of the $18 \mathrm{~S}$ ribosomal RNA gene. The $18 \mathrm{~S}$ rRNA gene was amplified using universal eukaryote primers Medlin A (5'-AACCTGGTTGATCCTGCCA GT-3') and Medlin B (5'-TGATCCTTCTGCAGGT TCACCT-3') and (Medlin et al. 1988). Approximately 10 to $50 \mathrm{ng}$ of genomic DNA were amplified using PCR beads as previously described, under the following conditions: an initial denaturation at $94^{\circ} \mathrm{C}$ for $1 \mathrm{~min}$, followed by 35 cycles of denaturation at $94^{\circ} \mathrm{C}$ for $30 \mathrm{~s}$, annealing at $55^{\circ} \mathrm{C}$ for $30 \mathrm{~s}$, and extension at $72^{\circ} \mathrm{C}$ for $90 \mathrm{~s}$. Final extension was at $72^{\circ} \mathrm{C}$ for $10 \mathrm{~min}$. If the ITS sequence was successfully amplified first, then only the ITS region was sequenced. Amplified small subunit (SSU) and ITS products were cloned directly into plasmid pCR 2.1 using the TOPO TA Cloning $^{\circledR}$ Kit (Invitrogen). Plasmids containing inserts were isolated and purified from recombinant E. coli using the GenElute ${ }^{\mathrm{TM}}$ Plasmid Mini-Prep Kit (SigmaAldrich). Plasmid inserts were sequenced on an ABI Prism 377 sequencer using Big-Dye ${ }^{\mathrm{TM}}$ terminators (Applied Biosystems) at the Guelph Molecular Supercentre (Laboratory Services Division, University of Guelph, Ontario, Canada). Sequences from each amoeba were identified by a Basic Local Alignment Search Tool (BLAST) sequence similarity search (Altschul et al. 1997). 


\section{RESULTS}

\section{Neoparamoeba PCR-RFLP}

The paired primers fNp-Hx49 rDNA and NLR 204/21 yielded an approximately 850 to $900 \mathrm{bp}$ PCR product from the 4 Neoparamoeba pemaquidensis reference isolates CCAP 1560/4, UA 6, ATCC 30735, ATCC 50172 (Fig. 1A). Detection of a similarly sized band that was lighter in staining intensity from the $N$. aestuarina isolate confirmed the expected cross-specificity of the forward primer fNp-Hx49 rDNA previously described by Wong et al. (2004). The outbreak isolate AVCLSC001 was successfully amplified with an approximately $900 \mathrm{bp}$ band, whereas the outbreak-associated isolate AVCLSC-002 was not (Fig. 1A).

The restriction patterns of the PCR products generated by AseI for the different incubation times are presented in Fig. 1B, and the number and calculated size of the restriction fragments are shown in Table 2. After $1 \mathrm{~h}$ of incubation, distinct cleavage patterns were observed from each of the Neoparamoeba pemaquidensis reference isolates and from the $N$. aestuarina isolate. By comparison to expected bands (Table 2), residual undigested or partially digested bands for all isolates except ATCC 30735 could be identified. After $3 \mathrm{~h}$ of incubation, distinct cleavage patterns were observed from each of the $N$. pemaquidensis reference isolates and from the $N$. aestuarina isolate. Residual undigested or partially digested bands were notable for most of the isolates. The cleavage pattern of the amplified isolate AVCLSC-001 matched the pattern of ATCC 50172, including the undigested band, and the AVCLSC-001 isolate was characterized as an isolate of the $N$. pemaquidensis ATCC 50172 strain.

\section{IRO PCR-RFLP}

The paired primers IRO-F-ITS and ITS4 successfully yielded an approximately $750 \mathrm{bp}$ PCR product from each IRO isolate from the 4 Neoparamoeba pemaquidensis reference isolates (CCAP 1560/4, UA6, ATCC 30735, ATCC 50172; Fig. 2A). The detection of a similarly sized band for IRO-N. aestuarina extended the amplification by the IRO universal forward primer IRO-F-ITS to other members of the genus Neoparamoeba. Template from the test sample AVCLSC-001 successfully amplified, yielding an approximately $750 \mathrm{bp}$ band, whereas that of the AVCLSC-002 isolate did not amplify (Fig. 2A).

The restriction patterns of the PCR products generated by AleI and NgoMIV for the different incubation times are presented in Fig. $2 \mathrm{~B}_{\text {; }}$ the number and calculated size of the restriction fragments are shown in
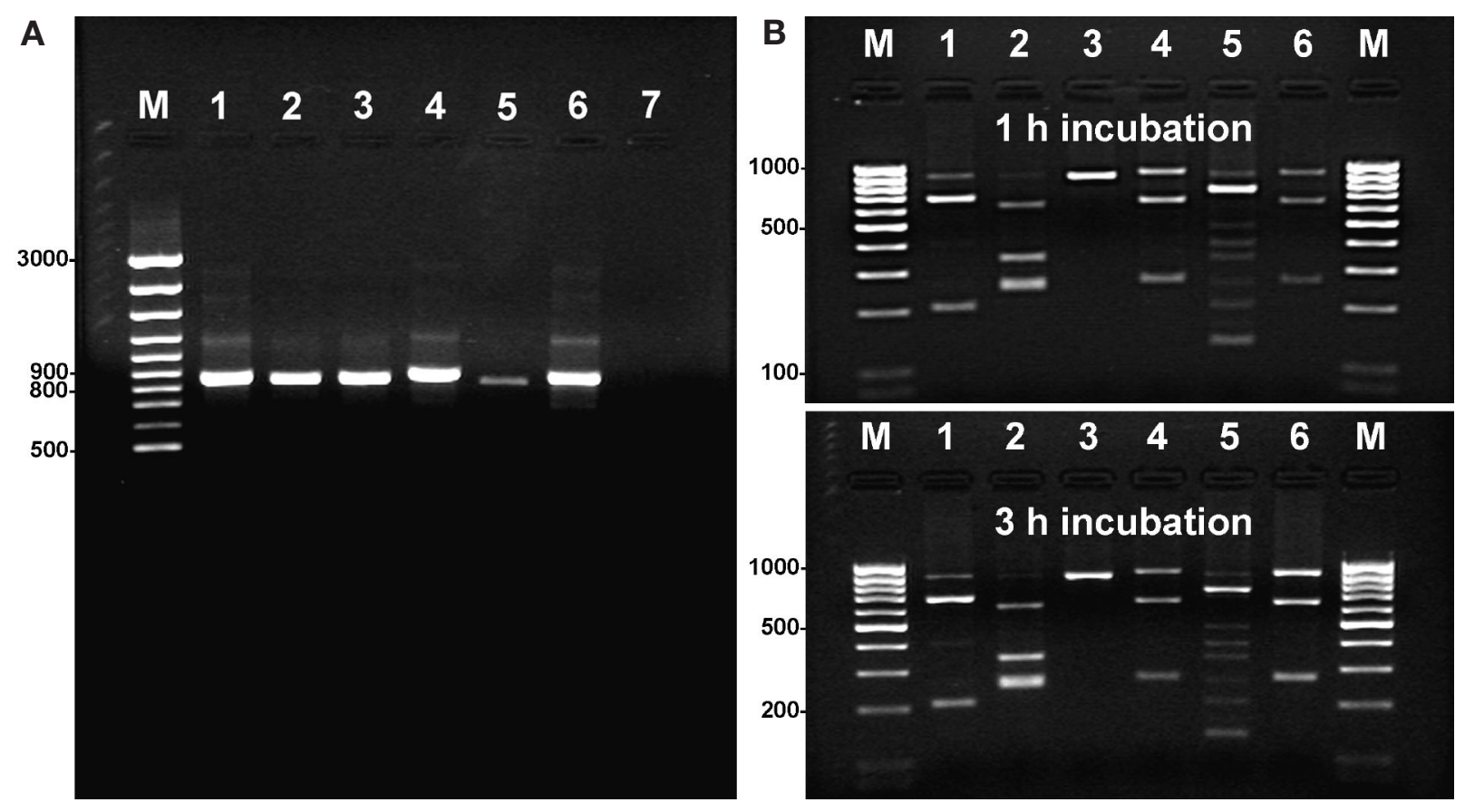

Fig. 1. Neoparamoeba spp. Agarose gel electrophoresis of (A) internal transcribed spacer (ITS) amplicons, and (B) restriction pattern of ITS amplicons digested with AseI after 1 and $3 \mathrm{~h}$ of incubation. Source of templates for Neoparamoeba spp. PCR: Lane 1, CCAP 1560/4; 2, UA 6; 3, ATCC 30735; 4, ATCC 50172; 5, ATCC 50806; 6, AVCLSC-001; 7, AVCLSC-002. Lane M: DNA ladder. Gel features: (A) $1.0 \%$ agarose, GeneRuler ${ }^{\mathrm{TM}} 100 \mathrm{bp}$ Ladder Plus, $80 \mathrm{~V}, 1 \mathrm{~h}$; (B) $2.0 \%$ agarose, GeneRuler ${ }^{\mathrm{TM}} 100 \mathrm{bp}$ Ladder, $80 \mathrm{~V}, 50 \mathrm{~min}$ 
Table 2. After $1 \mathrm{~h}$ of incubation, a distinct cleavage pattern was observed from each of the IRO-Neoparamoeba pemaquidensis reference isolates and from the IRO- $N$. aestuarina isolate. By comparison with the expected bands (Table 2), residual undigested bands for IRO-ATCC 50172 and IRO-ATCC 50806 isolates were evident, as were 2 partially undigested bands for IRO-CCAP 1560/4. After $3 \mathrm{~h}$ of incubation, a distinct cleavage pattern was observed from each of the IRO$N$. pemaquidensis reference isolates and from the IRO-

Table 2. Neoparamoeba spp. and respective endosymbiont Ichthyobodo necator related organism (IRO) restriction fragment length polymorphism (RFLP) patterns. Parallel comparison of number and size of restriction fragments obtained after NEBcutter 2.0 simulation (expected), or after 1 and $3 \mathrm{~h}$ incubation of PCR products. Neoparamoeba spp. amplicons were digested with Asel and IRO amplicons with AleI and NgoMIV. n.a.: not applicable

\begin{tabular}{|c|c|c|c|c|c|c|}
\hline \multirow[t]{2}{*}{ Isolate } & \multicolumn{2}{|c|}{ Expected } & \multicolumn{2}{|c|}{$1 \mathrm{~h}$ incubation } & \multicolumn{2}{|c|}{$3 \mathrm{~h}$ incubation } \\
\hline & $\begin{array}{l}\text { No. of } \\
\text { fragments }\end{array}$ & $\begin{array}{l}\text { Fragment sizes } \\
\text { (bp) }\end{array}$ & $\begin{array}{l}\text { No. of } \\
\text { fragments }\end{array}$ & $\begin{array}{l}\text { Approx. fragment } \\
\text { sizes (bp) }\end{array}$ & $\begin{array}{l}\text { No. of } \\
\text { fragments }\end{array}$ & $\begin{array}{l}\text { Approx. fragment } \\
\text { sizes (bp) }\end{array}$ \\
\hline CCAP 1560/4 & 2 & $665 / 210$ & 5 & $870 / 650 / 400^{\mathrm{a}} / 250^{\mathrm{a}} / 210$ & 3 & $870^{\mathrm{a}} / 650 / 210$ \\
\hline UA 6 & 3 & $340 / 265 / 255$ & 4 & $860^{\mathrm{a}} / 600^{\mathrm{a}} / 350 / 250^{\mathrm{b}}$ & 3 & $600^{\mathrm{a}} / 350 / 250^{\mathrm{b}}$ \\
\hline ATCC 30735 & 1 & 860 & 1 & 860 & 1 & 860 \\
\hline ATCC 50172 & 2 & $630 / 270$ & 3 & $900 / 650 / 280$ & 3 & $900 / 650 / 280$ \\
\hline ATCC 50806 & 2 & $730 / 130$ & 8 & $\begin{array}{l}860 / 680^{a} / 500^{a} / 410^{a} / \\
380^{a} / 270^{a} / 210^{a} / 140\end{array}$ & 8 & $\begin{array}{c}860 / 680^{a} / 500^{a} / 410^{a} / \\
380^{a} / 270^{a} / 210^{a} / 140\end{array}$ \\
\hline AVCLSC-001 & Tested & n.a. & 3 & $900 / 650 / 280$ & 3 & $900 / 650 / 280$ \\
\hline IRO-CCAP 1560/4 & 3 & $395 / 230 / 100$ & 5 & $650^{\mathrm{a}} / 500^{\mathrm{a}} / 400 / 240 / 120$ & 3 & $400 / 240 / 120$ \\
\hline IRO-UA 6 & 1 & 740 & 1 & 750 & 1 & 750 \\
\hline IRO-ATCC 30735 & 2 & $400 / 350$ & 2 & $400 / 360$ & 2 & $400 / 360$ \\
\hline IRO-ATCC 50172 & 2 & $390 / 235$ & 3 & $725 / 500 / 250$ & 3 & $725^{a} / 500 / 250$ \\
\hline IRO-ATCC 50806 & 2 & $370 / 365$ & 2 & $730 / 370^{\mathrm{b}}$ & 1 & $370^{\mathrm{b}}$ \\
\hline IRO-AVCLSC-001 & Tested & n.a. & 3 & $725 / 500 / 250$ & 3 & $725^{\mathrm{a}} / 500 / 250$ \\
\hline
\end{tabular}
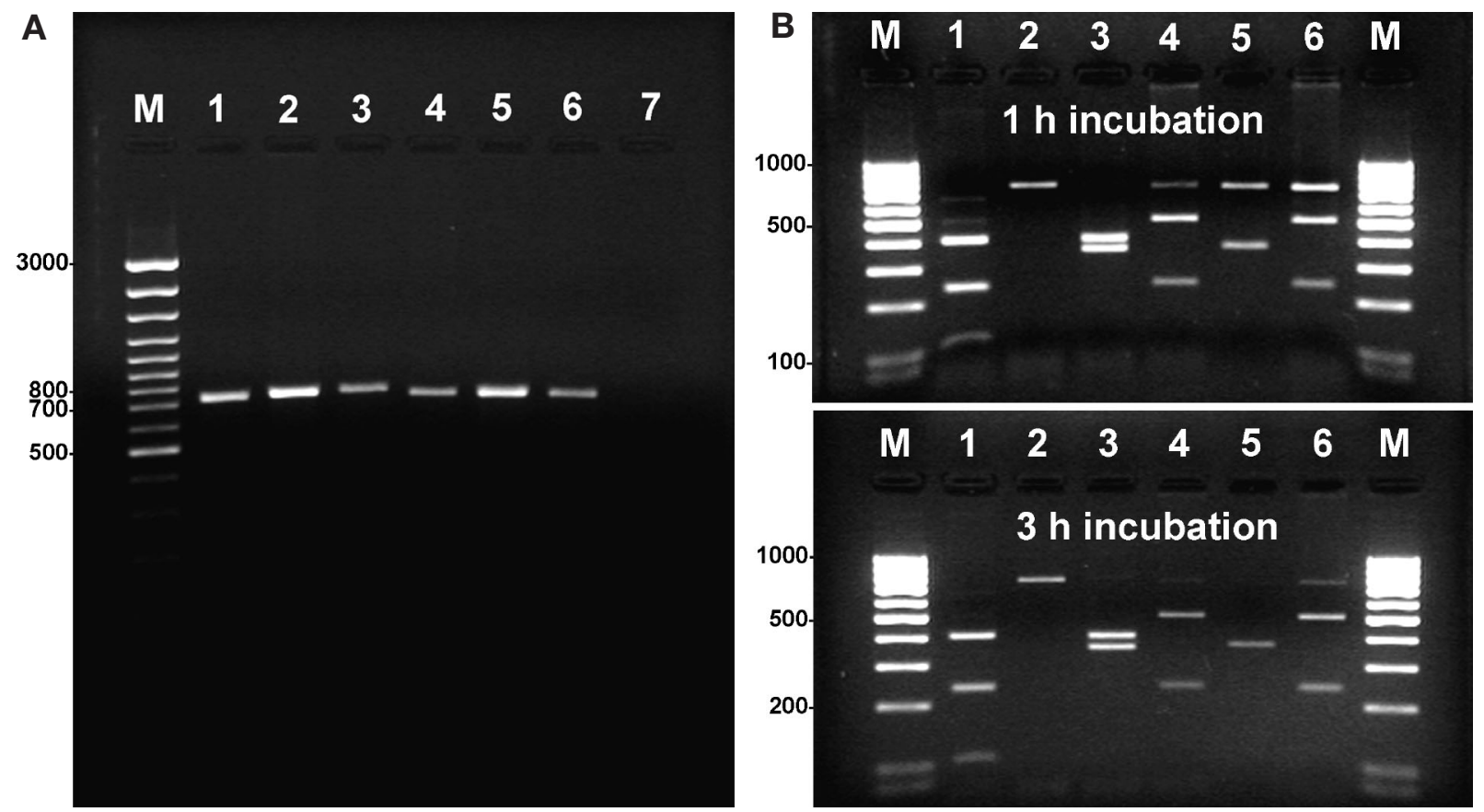

Fig. 2. Ichthyobodo necator related organism (IRO). Agarose gel electrophoresis of (A) ITS amplicons, and (B) restriction pattern of amplicons digested with AleI and NgoMIV after 1 and $3 \mathrm{~h}$ of incubation. Source of templates for IRO PCR: Lane 1, CCAP 1560/4; 2, UA 6; 3, ATCC 30735; 4, ATCC 50172; 5, ATCC 50806; 6, AVCLSC-001; 7, AVCLSC-002. Lane M: DNA ladder. Gel features: (A) $1.0 \%$ agarose, GeneRuler ${ }^{\mathrm{TM}} 100$ bp Ladder Plus, $80 \mathrm{~V}, 1$ h; (B) $2.0 \%$ agarose, GeneRuler ${ }^{\mathrm{TM}} 100$ bp Ladder, $80 \mathrm{~V}, 45 \mathrm{~min}$ 
$N$. aestuarina isolate; a single undigested band was identified from the IRO-ATCC 50172 isolate. The cleavage pattern of the episode isolate IRO-AVCLSC 001 was identical to the pattern of IRO-ATCC 50172, including the undigested band.

\section{Species confirmation}

After positive ITS region amplification, the AVCLSC-001 isolate was confirmed to be Neoparamoeba pemaquidensis and more specifically was most similar to ATCC 50172 using the ITS region sequences. The AVCLSC-001 amoeba ITS region sequence (GenBank accession number DQ660492) had 96 to $97.1 \%$ similarity with GenBank sequences for ATCC 50172 (DQ167546 to DQ167553) and only 83 to $89 \%$ similarity for all other N. pemaquidensis ITS sequences. Similarly, the AVCLSC-001 IRO ITS region sequence (DQ660493) had 99.6 to 99.9\% similarity with GenBank sequences for IRO-ATCC 50172 (DQ167501 to DQ167504) and only 92.4 to $97.1 \%$ similarity for all other $N$. pemaquidensis IRO ITS sequences. However, the ITS region of the second isolate, AVCLSC-002, was not amplified. Consequently, the 18S rRNA gene was partially sequenced (700 bp of the 5' end), and the isolate was identified as the leptomyxid amoeba Paraflabellula hoguae Sawyer, 1975 (99.4\% similarity with GenBank sequences AF293899 and AY277797).

\section{DISCUSSION}

Despite the ubiquity of Neoparamoeba pemaquidensis and its important role as a pathogen in commercial finfish aquaculture, there are several questions still outstanding regarding our current understanding of the biology of this amphizoic amoeba, from the variation in host range, to the modes of pathogenicity and suspected tissue tropism, to its worldwide geographical distribution. This lack of knowledge may be further compounded because currently available methods used to identify N. pemaquidensis (Elliot et al. 2001, Munday et al. 2001, Wong et al. 2004, Mullen et al. 2005) lack the ability to differentiate isolates at the subspecies level. In this study, 2 complementary PCRRFLP tests, based on the ITS regions from both $N$. pemaquidensis and its endosymbiont IRO, were developed and evaluated to determine their usefulness as methods to discriminate among different isolates.

Initial sequencing of the ITS regions from both the amoeba and endosymbiont showed sufficient interstrain variability to allow for further consideration in the development of a discriminative tool. However, the Neoparamoeba pemaquidensis ITS region contained significant intra-genomic variability (and consequently intra-isolate and intra-strain variability) that was earlier recognized as microheterogeneity (Caraguel et al. in press). This microheterogeneity within the ITS region introduced the dilemma of a potential 'moving target' for the marker (i.e. the possibility that a discriminative restriction enzyme site may be gained or lost in a number of copies within the genome and therefore may obscure the real value of the ITS region as a useful marker). The reduced to absent microheterogeneity within the IRO-ITS and the intimate association of the endosymbiont and its amoeba host makes the IRO-ITS a useful alternative target for discriminating between $N$. pemaquidensis isolates (Caraguel et al. in press).

The ITS region PCR-RFLP was successfully used to separate the 4 distinct strains of Neoparamoeba pemaquidensis using either the amoeba or the IRO derived markers. Faint extra bands, however, were present in all sample lanes following restriction enzyme digestions of 1 or $3 \mathrm{~h}$. These extra bands did not interfere with the comparison of the restriction patterns or with the interpretation of the results. Initially, these extra bands were thought to be the result of partial enzyme digestions from unsatisfactory restriction conditions (amplicon amount, endonuclease quantity and quality, buffer, incubation time). However, the survival of residual bands after optimizing the conditions revealed that microheterogeneity could account for appearing or disappearing restriction sites, dependent on the nature of the amplified ITS region copy. Therefore, based on the random proportion of amplified biased copies, microheterogeneity may explain the appearance of some unexpected light bands.

The effectiveness of the ITS region PCR-RFLP for differentiating strains of Neoparamoeba pemaquidensis was evaluated using amoebae isolated from Atlantic salmon during an AGD outbreak in Washington in the fall of 2004. DNA from the amoeba isolate AVCLSC-001 was successfully amplified using both Neoparamoeba and IRO region ITS primer sets and subsequently confirmed as belonging to the same strain as N. pemaquidensis (ATCC 50172). The second amoeba, AVCLSC-002, failed to produce a PCR product with either the Neoparamoeba or IRO region ITS primer sets. DNA from AVCLSC-002 was later amplified with 18S rRNA gene primers and subsequently identified by partial sequencing as Paraflabellula hoguae. The lack of amplified product from AVCLSC002 with either ITS primer set supported the specificity of the primers for Neoparamoeba spp. and the associated IRO endosymbiont. Paraflabellula hoguae has previously been isolated together with $N$. pemaquidensis from diseased fish gills (Elliot et al. 2001, Wong et al. 2004). Given the recent evidence for AGD being associated with a scuticociliate in the absence of 
any Neoparamoeba spp. in Irish salmonid aquaculture (Bermingham and Mulcahy 2004), it may be interesting to further investigate the potential role of this nonIRO carrying amoeba during AGD.

Interestingly, $20 \mathrm{yr}$ after Neoparamoeba pemaquidensis ATCC 50172 (originally deposited as Paramoeba pemaquidensis in 1987) was isolated from the infected gills of coho salmon Oncorhynchus kisutch reared in seawater net-pens in Puget Sound (Washington, USA; Kent et al. 1988), the same strain is still present and able to cause AGD in sea-cage raised Atlantic salmon. This represents an expansion of the known host range of this isolate to include both coho and Atlantic salmon. During this period, the ITS regions from both the amoeba and the endosymbiont were stable and may therefore represent excellent geographical markers for the $N$. pemaquidensis isolate, and clearly illustrates the critical importance that sub-species markers may have in disease monitoring, surveillance, and epidemiological studies.

To develop a diagnostic tool that can detect all Neoparamoeba species, specific primers must be designed and tested for the ITS region. In the present study, the specific forward primer fNp-Hx49 rDNA successfully amplified both $N$. pemaquidensis and also $N$. aestuarina that contained 1 imperfect match in 21 nucleotides (Wong et al. 2004). Unfortunately, this would not be the case for the recently described $N$. branchiphila that has been isolated from salmon gills and is associated with AGD (Dyková et al. 2005). This primer theoretically would not anneal to the $N$. branchiphila 18S rRNA gene, as the same region contains 7 non-matching nucleotides (Dyková et al. 2005). We therefore recommend that as new isolates become readily available in public culture collections they must first be amplified (using either the above or universal primers) and subsequently sequenced to select the most appropriate and inclusive primer sites and the best discriminative restriction endonuclease(s) according to the pool of isolates evaluated.

The discriminative power of using complementary molecular markers from both the host and endosymbiont will only be truly evaluated as the collection of readily available and new isolates of Neoparamoeba increases. However, if the level of microheterogeneity found within Neoparamoeba cannot be resolved through practical troubleshooting, as shown in the present study, then the IRO ITS should be considered as a useful internal control and an acceptable alternative target. Nevertheless, the presence of microheterogeneity within Neoparamoeba spp. could lower the analytical specificity of the PCR. The design of specific primers or probes to detect a particular $N$. pemaquidensis strain must be selected and screened with caution, as they could result in false positive amplicons if the primers anneal non-specifically on regions affected by microheterogeneity (ITS 1 and ITS 2; Caraguel et al. in press).

In the present study, the required quantity of genomic DNA was 5 to 10 times higher for IRO amplification than for the amoeba host. Consequently, we suggest using both markers in series or in parallel, by first using the Neoparamoeba ITS region to maximize the analytical sensitivity of the detection and then using the IRO ITS region to maximize the analytical specificity of the characterization. Moreover, in this study, extraction and amplification protocols were established and standardized using pure amoeba cultures. At least 2 factors affect the sensitivity of amoeba detection in crude samples, i.e. the efficiency of DNA extraction from low numbers of amoebae in a complex sample matrix, and the possible presence of PCR inhibitors in the preparation (Elliot et al. 2001, Wong et al. 2004). The use of the methods developed in this study with isolated amoeba cultures will require further refinement and optimization for incorporation into diagnostic studies from amoeba-infected tissues and environmental samples to ensure analytical sensitivity.

The Neoparamoeba ITS inter-strain variability in conjunction with the complementary IRO ITS represents very attractive alternative features that could be used to develop more specific in situ hybridization detection. Incorporating these subspecies markers into infection experiments may help answer some of the unresolved questions surrounding the biology of Neoparamoeba.

Acknowledgements. We thank Dr. R. Gast for critical comments on the manuscript and Dr. H. Mitchell, Novartis-Aqua Health, for providing infectious material from Atlantic salmon in 2004. The authors also thank B. Després for technical assistance. Funding for the Canadian Lobster Health Research Project delivered by the AVC Lobster Science Centre represents a consortium of private sector companies, fishermen's organizations, First Nations, and provincial and federal government agencies, including the Atlantic Innovation Fund through the Atlantic Canada Opportunities Agency.

\section{LITERATURE CITED}

Adams MB, Ellard K, Nowak BF (2004) Gross pathology and its relationship with histopathology of amoebic gill disease (AGD) in farmed Atlantic salmon, Salmo salar L. J Fish Dis 27:151-161

Altschul SF, Madden TL, Schaffer AA, Zhang J, Zhang Z, Miller W, Lipman DJ (1997) Gapped BLAST and PSIBLAST: a new generation of protein database search programs. Nucleic Acids Res 25:3389-3402

Bermingham ML, Mulcahy MF (2004) Environmental risk factors associated with amoebic gill disease in cultured salmon, Salmo salar L., smolts in Ireland. J Fish Dis 27: 555-571

Beszteri B, Acs E, Medlin LK (2005) Ribosomal DNA sequence 
variation among sympatric strains of the Cyclotella meneghiniana complex (Bacillariophyceae) reveals cryptic diversity. Protist 156:317-333

Brown GD, Hudson KL, Reece KS (2004) Multiple polymorphic sites at the ITS and ATAN loci in cultured isolates of Perkinsus marinus. J Eukaryot Microbiol 51:312-320

Caccio SM, Thompson RCA, McLauchlin J, Smith HW (2005) Unravelling Cryptosporidium and Giardia epidemiology. Trends Parasitol 21:430-437

Cann JP, Page FC (1982) Fine-structure of small free-living Paramoeba (Amoebida) and taxonomy of the genus. J Mar Biol Assoc UK 62:25-43

Caraguel CGB, O'Kelly CJ, Legendre P, Frasca S Jr, Gast RJ, Després BM, Cawthorn RJ, Greenwood SJ (in press) Microheterogeneity and coevolution: an examination of rDNA sequences characteristics in Neoparamoeba pemaquidensis and its prokinetoplastid endosymbiont. J Eukaryot Microbiol

Douglas-Helders M, Carson J, Howard T, Nowak B (2001) Development and validation of a new dot blot test for the detection of Paramoeba pemaquidensis (Page) in fish. J Fish Dis 24:273-280

Dyková I, Novoa B (2001) Comments on diagnosis of amoebic gill disease (AGD) in turbot, Scophthalmus maximus. Bull Eur Assoc Fish Pathol 21:40-44

Dyková I, Figueras A, Novoa B (1995) Amoebic gill infection of turbot, Scophthalmus maximus. Folia Parasitol 42:91-96

Dyková I, Figueras A, Novoa B, Casal JF (1998) Paramoeba sp., an agent of amoebic gill disease of turbot Scophthalmus maximus. Dis Aquat Org 33:137-141

Dyková I, Figueras A, Novoa B (1999) Epizoic amoebae from the gills of turbot Scophthalmus maximus. Dis Aquat Org 38:33-38

Dyková I, Figueras A, Peric Z (2000) Neoparamoeba Page, 1987: light and electron microscopic observations on six strains of different origin. Dis Aquat Org 43:217-223

Dyková I, Fiala I, Lom J, Lukes J (2003) Perkinsiella amoebaelike endosymbionts of Neoparamoeba spp., relatives of the kinetoplastid Ichthyobodo. Eur J Protistol 39:37-52

Dyková I, Nowak BF, Crosbie PB, Fiala I, Peckova H, Adams MB, Machackova B, Dvorakova H (2005) Neoparamoeba branchiphila n. sp., and related species of the genus Neoparamoeba Page, 1987: morphological and molecular characterization of selected strains. J Fish Dis 28:49-64

Elliot NG, Wong F, Carson J (2001) Detection and abundance of Paramoeba species in the environment. FRDC Project 98/209, CSIRO Marine Research, Hobart, p 1-68

Fiala I, Dyková I (2003) Molecular characterisation of Neoparamoeba strains isolated from gills of Scophthalmus maximus. Dis Aquat Org 55:11-16

Hall TA (1999) BioEdit: a user-friendly biological sequence alignment editor and analysis program for Windows 95/98/NT/XP. Nucleic Acids Symp Ser 41:95-98

Howard T, Carson J (1993) Verification that Paramoeba species are consistently associated with gill damage in fish affected with amoebic gill disease. In: Valentine P (ed) Proceedings of the SALTAS research and development review seminar. Salmon Enterprises of Tasmania, Dover, Tasmania, pp 69-80

Editorial responsibility: Dieter Steinhagen, Hannover, Germany
Jones GM (1985) Paramoeba invadens n. sp. (Amoebida, Paramoebidae), a pathogenic amoeba from the sea urchin, Strongylocentrotus droebachiensis, in eastern Canada. J Protozool 32:564-569

Kent ML, Sawyer T, Hedrick RP (1988) Paramoeba pemaquidensis (Sarcomastigophora: Paramoebidae) infestation of the gills of coho salmon Oncorhynchus kisutch reared in sea water. Dis Aquat Org 5:163-169

Medlin L, Elwood HJ, Stickel S, Sogin ML (1988) The characterization of enzymatically amplified eukaryotic 16S-like rRNA-coding regions. Gene 71:491-499

Moreira D, Lopez-Garcia P, Vickerman K (2004) An updated view of kinetoplastid phylogeny using environmental sequences and a closer outgroup: proposal for a new classification of the class Kinetoplastea. Int J Syst Evol Microbiol 54:1861-1875

Morrison RN, Crosbie PBB, Cook MT, Adams MB, Nowak BF (2005) Culture gill-derived Neoparamoeba pemaquidensis fails to elicit amoebic gill disease (AGD) in Atlantic Salmon Salmo salar. Dis Aquat Org 66:135-144

Mullen TE, Russell S, Tucker MT, Maratea JL and 7 others (2004) Paramoebiasis associated with mass mortality of American lobster Homarus americanus in Long Island Sound, USA. J Aquat Anim Health 16:29-38

Mullen TE, Nevis KR, O'Kelly CJ, Gast RJ, Frasca S (2005) Nuclear small-subunit ribosomal RNA gene-based characterization, molecular phylogeny and PCR detection of the Neoparamoeba from western Long Island Sound lobster. J Shellfish Res 24:719-731

Munday BL, Lange K., Foster CK, Lester RJG, Handlinger J. (1993) Amoebic gill disease of sea-caged salmonids in Tasmanian waters. Tasman Fish Res 28:14-19

Munday BL, Zilberg D, Findlay V (2001) Gill disease of marine fish caused by infection with Neoparamoeba pemaquidensis. J Fish Dis 24:497-507

Peglar MT, Amaral Zettler LA, Anderson OR, Nerad TA and 6 others (2003) Two new small-subunit ribosomal RNA gene lineages within the subclass Gymnamoebia. J Eukaryot Microbiol 50:224-232

Ristaino JB, Madritch M, Trout CL, Parra G (1998) PCR amplification of ribosomal DNA for species identification in the plant pathogen genus Phytophthora. Appl Environ Microbiol 64:948-954

Ruggiero MV, Procaccini G (2004) The rDNA ITS region in the lessepsian marine angiosperm Halophila stipulacea (Forssk.) Aschers. (Hydrocharitaceae): intragenomic variability and putative pseudogenic sequences. J Mol Evol 58:115-121

Van der Auwera G, Chapelle S, De Wachter R (1994) Structure of the large ribosomal subunit RNA of Phytophthora megasperma, and phylogeny of the oomycetes. FEBS Lett 338:133-136

Wong FY, Carson J, Elliott NG (2004) 18S ribosomal DNAbased PCR identification of Neoparamoeba pemaquidensis, the agent of amoebic gill disease in sea-farmed salmonids. Dis Aquat Org 60:65-76

Zilberg D, Gross A, Munday BL (2001) Production of salmonid amoebic gill disease by exposure to Paramoeba sp. harvested from the gills of infected fish. J Fish Dis 24:79-82

Submitted: November 28, 2006; Accepted: February 23, 2007 Proofs received from author(s): May 28, 2007 